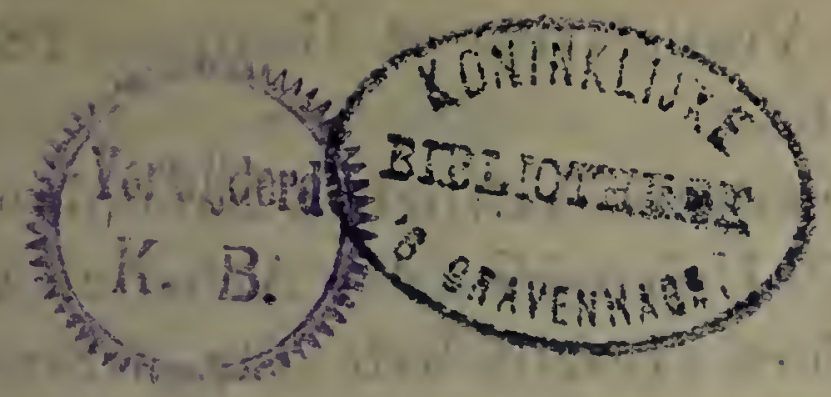

\title{
INDEX SCRIPTORUM
}

AD MEDICINAM E'T SCIENTIAS NATURALES SPECTANTIU M

\section{D-ris Ludovici Adolphi Neugebaueri,}

G GNIATRICEN IN IMPERIALI LITERARUM UNIVERSITATE VARSAVIENSI DOCENTIS.

\section{УЧЕНЫЕ ТРУДЫ}

ДОЦЕНТА ПО КАӨЕДРњ АКУUЕРСТВА,

П-ра мөд. и хир. Пюдовика Адольфа Нөгігөбауөра.

1. „De calore plantarum. Dissertatio inauguralis phytophysiologica, quam consensu et auctoritate gratiosi Medicorum Ordinis in Literarum Universitate Vratislaviensi ad Doctoris medicinue et chirurgiae gradum rite acquirendum die 9 . mensis decembris a. 1845. palam defensurus est Ludovicus Neugebauer". Vratislaviae. 50 paginae. 8-ro.

2. "Systema venosum avium cum eo mammalium et inprimis hominis collatum. Commentatio anatomica a Medicorum Ordine in Literarum Universitate Vratislaviensi praemio ormata, auctore Ludovico Adolpho Neugebauer". Cum tabul. XV lithograph. In opere: Novorum actorum Academiae Caesarea Leopoldino-Carolinae naturae curiosorum Vol. XXI pars posterior. (Verhandlungen der Kaiserlichen Leopoldiniseh-Carolinischen 
Akademie der Naturforscher. Des 13-ten Bandes 2-te Abtheilung). Vratislaviae et Bonnae, 1845. 4-to. Pag. 517-697. Tab. 36-50. - Seorsim excusa Vratislaviae et Bonnae, 1845. 4-to. 181 paginae. Cum XV tabulis.

3. ,Ueber die naturwissenschaftlichen Sammlungen des Jardin des plantes zu Paris". Uebersicht der Arbeiten und Veränderungen der Schlesischen Gesellschaft für vaterländische Kultur im Jahre 1847. Breslau, 1848. 4-to. Seite 83-85.

4. „Ueber die Pariser Hospitäler”. Uebersicht der Arb. u. Veränd. der Schles. Gesellsch. für vaterl. Kultur im J. 1847. Breslau, 1848. S. 226-227.

5. „Uebersicht der Vorfälle in der königlichen Gebäranstalt in Breslau im Jahre 1846" entworfen nach den Buchern der Anstalt. Uebersicht der Arb. u. Veränd. der Schles. Gesellsch. fur vaterl. Kultur im J. 1847. Breslau. 1848. S. 239-243.

6. ,Fall von Fibroid der äusseren weiblichen Geschlechtstheile". Uebersicht der Arb. u Veränd. der Schles. Gesellsch. für vaterl. Kultur im J.1848. Breslau, 1849. 4-to S. 167-170. -Zeitschrift für klinische Medicin, mit dem Verein für physiologrische Heilkunde in Breslau herausgegeben von Dr Frredrich Günsburg. Erster Jahrgang. Breslau, 1850. 8-vo. S. 73-76.

7. „Fall von ungewöhnlicher Länge der Nabelschnur”. Uebersicht der Arb. u. Veränd. der Schles Gesellsch. für vaterl. Kultur in J. 1848. Breslau, 1849. 4-to. S. 171.

8. Die asiatische Cholera, ihre Behandlung und die Mittel sich gegen sie \%u verwahren, bearbeitet von Dr. Karl Julius Wilhelm Paul Remer und Dr Ludwig Adolph Neugebauer. Görlitz, 1848. X und 117 Seiten 8-vo.

9. "Ueber das Auftreten der Leber im Nabel als Fehler der ersten Bildung". Nene Zeitschrift für Geburtskunde, heraus. gegeben von Busch, Ritgen und v. Siebold. Band 27. Berlin, 1850. 8-vo. S. 64 - 78. Mit einer Tafel Abbildungen.-Uebersicht der Arb. u. Veränd. der Schles. Gesellsch. für vaterl. Kultur im J. 1849. Breslau, 1850. 4-to. S. 145-150.-Zeitschrift für klinische Medicin, heransgegeben von Friedrich Günsburg. Band 8. (Achter Jahrgang). 185̄8. Breslau. 8-vo S. 435-441. 
10. „Fall von Contractur des linken Schenkels im Kniegelenk als Folge von Verbrennung". Zeitschrift für klinische Medicin, herausgegeben von Friedrich Günsburg Band 2. (Zweiter Jah rgang). 1851. Breslau. 8-vn. S. 473--476.

11. "O odłożeniu wypadłego sznurka pepkowego". Pamiętnik Towarzystwa Lekarskiego Warszawskiego. Tom 27. Warszawa. 1852. 8-vo. Stronnice 68-94. Z rysunkami. (0 вправленіи выпавшей пуповины).

12. „Ueber die Omphalotaxis oder Reposition der vorgefallenen Nabelschnur". Zeitschrift für klinische Medicin, herausgegeben von Friedrich Günsburg. Band 3. (Dritter Jahrgang). 1852. Breslau. 8-vo. S. 33-47. (Mit Abbildungen).

13. „Duplicität des grössten Theils des Körpers, beobachtet bei einem jungen Hasen". Mit einer Steindrucktafel. Verhandlungen der Kaiserlichen Leopoldinisch-Karolinischen Akademie der Naturforsoher. Des 16-ten Bandes 1-ste Abtheilung. (Nororum Actorum Academiae Caesareae Leopoldino-Carolinae naturae curiosorum voluminis XXIV pars prior). Breslau und Bonn, 1854. 4-to. S. 15-48. Tafel 15.-Besonderer Abdruck. Breslau und Bonn, 1854. 34 Seiten 4-to. Mit 1 Steindrucktafel.

14. „Sprawozdanie z czynności Szpitala Świętej Trójcy w Kaliszu w roku 1854". Pamiętnik Towarzystwa Lekarskiego Warszawskiego. Tom 33. Warszawa, 1855. 8-vo. Str. 185-266 і 342-344. Z figurami chromolitografowanemi. (Отчет"ъ о дъвательности Больницы Святой Тройды в'ь Калиш'ь за 1854 гол'ь).

15. „Sprawozdanie \# czynności Szpitala Świętej Trójcy w Kaliszu w roku 1855". Pamiętnik Towarzystwa Lekarskiego Warszawskiego. Tom 36. Warszawa, 1856. 8-vo. Str. $42-110 \mathrm{i}$ 169--219. (Z rycinami).- Oddzielne odbicie. Warsza wa, 1856. 125 stronnic 8-vo. Z rysunkami. (Отчеть о д'вятельности Больницы Святой Тройцы в'ь Калишґ за 1855 год'ь. Статья эта содержить м. пр.:

1. Наблюденія о тифы и лечепіи его посредством' іодистаго калія, (странницы 51-102,一отдйльный оттискь стр. 16-62);

i. Oписавіе новаго маточнаго зеркала (стр. 174-183, отд'льный оттискь стр. $76-86$, с' рисунками, фиг. 1-4);

3. Опытное изсльдованіе уды.льняго въса зародыша и вліянія 
этого же въса на положеніе зародыша въ матк' (стр. 207-210, -отдћльный оттискъ стр. 110-113);一и

4. Oпытное изсльвдованіе пуповины относительно скрюченнаго ея вида (стр. $211-216$, - отдњльный оттискь стр. $113-$ 120, съ рисункомъ, 一фиг. 7.).

16. „Sprawozdanie z czynności Szpitala Świetej Trójcy w Kaliszu w roku 1856". Pamiętnik Towarzystwa Lekarskiego Warszawskiego: Tom 38. Warszawa, 1857. 8-vo. Str. 235--261. -Oddzielne odbicie. Warszawa, 1857. 29 stronnic $\mathcal{S}$-vo. (Отчеть o дывятельности Больницы Святой Тройцы въ Калишґ за 1856 г.).

17. „Ein neuer Mutterspiegel”. Amtlicher Bericht über die zwei-und dreissigste Versammlung deutscher Naturforscher und Aerzte zu Wien im September 1856. Herausgegeben von Hyrtl und Schrötter. Wien, 1858. 4-to. S. 225-237. Mit einer Tafel Abbildungen.

18. Morphologie der menschlichen Nabelschnur. Breslau, 1858. 80 Seiten 8-vo mit 63 lithographirten Figuren auf $2 \mathrm{Ta}$ feln. (Перечень этой статьи сообщена в's: Monatsschrift fur Geburtskunde und Frauenkrankheiten, herausgegeben von Crede, E. Martin, von Ritgen, von Siebold. Band 14. Berlin, 1859. 8-vo. S. $317-320$ ).

19. Wykład akuszeryi. 'Tom pierwszy, część pierwsza, w Warszawie, 1860 r. 246 stronnic. 8-vo. (Wstęp i część przygotowawcza). (Курсь акушерства. -Введеніе и пред'ьуготовительная часть).

20. „Nowy spośbb robienia krwawego szwu krocza i sromu". Pamiętnik Towarzystwa Lekarskiego Warszawskiego. Tom 43. Warszawa, 1860. 8-vn. str. 387-412. Z rycinami. Oddzielne odbicie. Warszawa, 1860. 30 stronnic 8-vo. (Новый способ'ь процзведенія кроваваго шва промежности и срамной разщелины).

Эта статья кром' того отпечатана также и въ сочиненіи: Rocznik Ces.-Król. Towarzystwa Naukowego Krakowskiego. Tom 27, Kraków, 1860. 8-vo. str. 296-320: „Nowy sposób robienia szwu krocza i sromu”. Z figurami chromolitografowanemi. - Oddzielne odbicie. (Kraków, 1860). 25 stronnic' 8-vo. 
21. „Przypadek operowanego thuszczaka (lipoma) olbrzymiej wielkości". Pamiętnik Towarzustwa Lekarskiego Warszawskiego. Tom 44. Warszawa, 1860. 8-vo. str. 124-126. Z drzeworytem.-(Случай оперированной липоматозной опухолп громадныхъ размъровъ).

22. „Sprawozdanie z czynności Wydziału gynekologicznego 35-go zebrania niemieckich badaczów natury i lekarzy, odbytego w Króleweu w dniach od 16 do 21 września 1860 r." Pamiętnik Towarzystwa Lekarskiego Warszawskiego. Tom 44. Warszawa, 1860. 8-vo. Str. 336-343. - Oddzielne odbicie. Warszawa, 1860. 8 stronnic 8-vo. (Отчетъ о диялтельности отд'в-

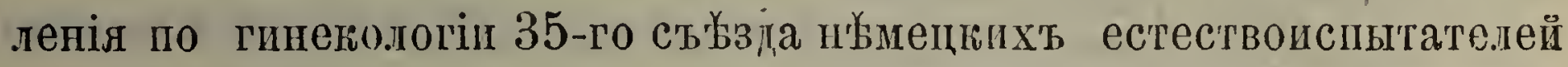
и врачей вт Кенигсбергев отъ 16 до 21 сентлбрл 1860 г.).

23. "Anatomia opisowa ciala ludzkiego podlug. Józefa Hyrtla przez Ludwika Adolfa Neugebanera. Drieło ozdobione drzeworytami. Tom 1. Warszawa, 1860. IV i 534 stronnic 8-vo. - Anatomia opisowa ciala ludzkiego podkug Józefa Hyrtla, przez Ludwika Adolfa Neugebauera i Janusza Fierdynanda Nowakowskiego. Tom 2. Warszawa, 1864. IIJ i 362 stronnic 8-ro. Z 102 drzewory tami w tekscie i wizerunkiem Jana Ew. Purkyniegо. (Описательная апатоміл человъчесгато тъ.ла. Шервый томъ содержитьь остеологію и міологію, 一второй же спланхологію).

24. "Neue Methode der blutigen Dammnaht und der blutigen Naht uberhaupt". Königsberger medicinisshe Jahrbucher. Jahrgang 1861. Königsberg. 8-vo-_Medizinisch-chirurgische Rundschau, Monatschrift für die gesammte praktische Heilkunde des In-und Auslandes. Redakteur: Markbreiter. MitRedakteur: Schnitzler. Jahrgang 3, Band 2, Heft 3. Juni 1862. Wien. 8-vo. S. $161-176$.

25. „Nowy sposób ułatwienia operacji przetoki pęcherzopochwowej". Pamiętnik Towar/ystwa Lekarekiego Warszawskiego. Tom 45. Warszawa, 1861. 8-vo. str. 1-21. Z drzeworytami w tekscie. Oddzielne odbicis. Warszawa, 1861. 23 str. 8-vo. (Новый способъ облегчамцій огерацію пузнрно-влагалицнаго свища).

26. „O połogowym zakrzepie i zapalenin ży (phlebothrombosis et phlebitis puerperalis)". Pamiętnik Towar\%ystwa Lekarsk. 
Wars\%. Tom 46. Warszawa, 1861. 8-vo. Str. 1-56. Do tego jako przyczynek: ,Przypadek ciezżkiej pyemii z pologowego zakrzepu i zapalenia ży wynikłej, a zupełnem wyzdrowieniem chorej zakończonej". Pamiętnik Tow. Lek. Tom 46, str. 5764. - Oddrielne odbicie wyżej wymienionej rozprawy (wraz z przyczynkiem). Warszawa 1861. 64 stronnic. 8-vo.-(0 Iroсльродовом' тромбоз' и воспаленіи венљ,-и: случай тяжкой піэміи, произшедшей оть шуэрперальнаго воспаленія и тромбоза венъ съ благополучным'ь исходом'ь).

27. „Polożenie plodu w macicy". Pamiętnik Towarzystwa Lekarskiego Warszawskiego. Tom 46. Warszawa, 1861. 8-vo Str. 217-266. Z drzeworytami w tekscie. (Положеніе младенца въ мaTt'b).

28. „Przypadek rozdarcia się śródkrocza u rodzącej dokniętej zrostem warg sromowrch większych i wystapienie, ta droga plodu w sposób nadzwyczajny". Pamiętnik Towarzystwa Lukarskiego Warszawskiego. Tom 47. Warszawa, 1862. 8-vo. Str. 69-90. Z drzeworytami w tekscie. - Oddzielne odbicie. Warszawa, 1862. 24 stronnic 8-vo. (Случай разрыва промежности у родительницы страдающей сращеніем' больших' дъ́тородныхъ губ'ь и выхода этим'ь путьем'ь младенца необыкновенным' образом').

29. „Odpowiedź na artykul Dru Morgensterna ogloszony pod tytulem ,W rjaśnienie” w poszycie piątym tomu 47, $\mathrm{Pa}$ miętnika Towaryystwa Lekarskiego Warszawskiego". Pamiętnik Towarzystwa Lekarskiego Warszawskiego. Tom 48. Warszawa, 1862. 8.vo. Str. 112-125. Odbicie oddzielne. Warszawa, (1862). 14 stronic. 8-vo. (Отв'ь'т на статью Дра Моргенштерна обнародованную подт заглавіемъ: „Разъясненіе” в'ь пятом'ь вынускъ 4. го тома трудовь Варшавскаго Медицинскаго Общества).

30. „Fragmate aus Reisebriefen". Warsobaure Zeitung. Vierter Jahrging. 1862. Warschau. Folio. November: Nr. 263266, 268-273; December: Nr. 274-279.-Besonderer Abdruck. Warschan, 1862. 41. Seiten 8 vo.-(Путешествіе совершен ное в'ь Реіхенгаль, Рагац'ь, Пфефиерс'ь, Санктъ-Морицъ, Миланъ, Венецію и к'ь Адельсбергспой пещеръ). 
31. Wspomnienia z zakładu położniczego w Medjolanie. Rozprawa czytana na posiedzeniu Towarzystwa Lekarskiego Warszawskiego w dniu 7 października 1862 roku," Tygodnik Lekarski. Redaktor: Natanson. Rok 17. 1863. Warszawa. 4-to Nr. 8 (str. 61-63) i Nr. 10 (str. 77-82). - Oddzielne odbicie. Warszawa, 1863, 32 stromnic 8-vo. (Воспоминаніа из'ь родовспомагательнаго заведенія в'ь Милан'ь. Статья эта содержить м. пр. описаніе кифотическаго таза как'ь новаго въ акушерском'ь отнопеніи типа поперёгь с суженнаго таза).

32. „Beitrag zur.Lehre von der Selbstentwickelung des Kindes aus Schulterlage." Deutsche Klinik, Zeitung für Beobachtungen aus deutschen Kliniken und Krankenhäusern, herausgegreben von Alex. Göschen. Jahrgang 1863 Berlin, 4-to. Nr. 13. Seite 127 -128. (Дополненіе к' ученію о рожденіи м.ладенца шлечем' путем's так'ь называемаго самопрошзвольнаго освобожденія (erolutio spontanea).

33. „Bidrag til Laeren om Barnets Selvudvikling af Skulderleie, af Dr Ludwig Adolf Neugebauer." Forhandlinger i det Norske medicinske Selskab i 1863. (Aftrykt fra Norsk Magazin for Laegevidenskaben). Christiania, 1863. 8-vo. Side 61-66. (Дополненіе къ ученію о рожденіи младенца плечемъ путем'ь самопроизвольнаго освобожґденія). - Эта статья-пичто другое, как'ь статья 츠. 31 на норвегском' языкъ.

34. „Beitrag zur Lebre von der stellbaren Kugelnaht”. Zeitschrift der k. k. Gesellschaft der Aerzte in Wien. Redigirt von Duchek, Schauenstein. Jahrgang. 1863. Wien. 8-vo. Nr. 32, S. $249-252,-\mathrm{Nr}$. 33 , S. $257-260$. Mit 4 Holzsuhnitten. (Дополненіе к'Б ученіг о гариковатомъ швь).

35. „Przypadek wodosteku rdzeniowego (Hydrorrhachis) uleczonego siłą natury przez pęknięcie samodzielne guza wodostekowego jeszcze podczas życia wewnątrz-macicznego". Pamiętnik Towarzystwa Lekarskiego Warszawskiego. Tom 52. Warszawa, 1864 8-vo. str. 405-408.-Oddzielne odbicie. (Warszawa. 1864). 3 stronnice 8-vo.—(Суучай скопленія суббъарахноцдальной жидкости спиннаго мозга, излеченнаго силами природы самогрошзвольным'ь лошнутіем'ь опухоли еще во время утробной жиззни) 
36. „Przy padek polożniczy”. Pamiętnik Towarzystwa Leka!skiego Warszawskiego. Tom 52. Warszawa, 1864. 8-vo. (Str. 436-441: „Posiedzenie dnia 9 października 1864”). Str. 437 438. (Акушерскій случай. Роды двуглаваго младенца).

37. „O zarośnieniu cewki moczowej u niewiast, z przytoczeniem trzech pomyślnie uleczonych przypadków przetoki pęcherzopochwowej powikłanej z tem cierpieniem". Tygodnik Lekarski. Redaktor: Natanson. Rok 18. 1864. Warszawa. 4-to. Nr. 10, str. $73-75 ;$ Nr. 11 , str. $82-85$; Nr. 14, str. 106-110; Nr. 15, str. $115-119 ;$ i Nr. 16, str. 123-125. Z drzeworytami w tekscie.-Oddzielne odbicie. Warszawa, 1864. 46 stronnic 8-vo. (O заращеніи мочеиспускательнаг) канала у женщинъ, съ приложеніемь трех' благополучно излеченных' случаев'ь иузыровлагалищнаго свица сопрлженнаго съ этимъ страданіемъ).

38. „Beitrag zur Lehre von der durch partielle Verwachsung der Rima yulvae erschwerten Geburt. Mit 3 Tafeln Abbildungen". Klinische Beiträge zur Gynäkologie. Unter Redaction von $W$. A. Freund herausgegeben von $J$. W. Betschler, W. A. Freund und M. B. Freund. Drittes Heft. Breslau, 1865. 8-vo. S. 1-42. Tafel 1-3.--Besonderer Abdruck. (Breslau, 1865). 42 Seiten 8-yo. Mit 3 Tafeln.

39. „Ueber einen Geburtsfall eines doppelköpfigen Kindes". Monatsschrift fur Geburtskunde und Frauenkrankheiten, herausgegeben von Credé, Hecker, E. Martin, von Ritgen. Band. 26. Berlin, 1865. 8-vo. (S. 421-446: "Vierzigste Versammlung deutscher Naturforscher und Aerzte in Hannover im Jahre 1865. Verhandlungen der Section fül Gynäkologie. Berichtet vón $W$. Kiinecke"). S. 421-422. (Этот"ь же случай, к'ь которому относится 32 статья).

40. „Fall von einer durch die Natur begonnenen und durch die Kunst mit Erfolg beendeten Entfernung eines Myoms der Gebärmutter". Monatsschrift für Geburtskunde und Frauenkrankhoiten, herausgegeben von Credé, Hecker u.s w. Band 28. Berlin, 1866. 8-vo. S. 401-414. Separat-Abdruck. Leipzig. 1866). 16 Seiten. 8-vo. (Случай вылущенія большой міоматозной оцухоли матки сквозь самопроизвольно произшедшее отнерстіе в'ь брюшной ст'ьнк', съ благополучным'ь исходом'ь). 
41. „Przyczynek do nauki o rodzeniu się tpodu barkiem w drodze tak zwanego wyklucia się samowolnego. (evolutio spontanei foetus)". Tygodnik Lekarski. Redaktor: Natanson. Rok 19. 1865. Warszawa. 4-to. Nr. 5l, str. 401-404. - Oddzielne odbicie. Warszawa, 1866. 10 stronnic 8-ro. (Доцолненіе๘ъ ученію о рожденіи младенца ш.лечем'ь путемъ таг' называемаго самопроизвольнаго освобождепія - evolutio spontanea). Это ста-

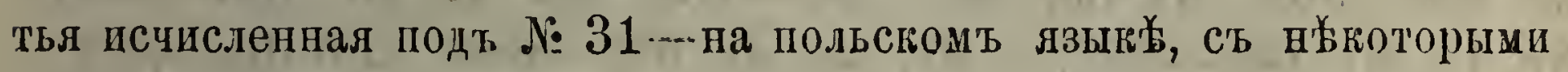
перем'ьнами.

42. „Odjęcie za pom oca galwano-kaustyki narośli mięsakowej ściany brzusznej u kobiety ciężarnej, dokonane z pomyślnym skutkiem." Klinika, ezasopismo poświęcone umiejętnościom lekarskim. Relaktor: Dobieszewski. Rok 1, Tom. 1. Warszawa, 1867. 8-vo. Nr. 5, str. $71-73$. Z drzeworytem w tekscie.-Oddzielne odbicie. (Warszawa, 1867). 3 stronnice 8-yo. (Отнятіе, помощію гальвано-каустическаго прибора, сарко-матозной опухоли брюшной стйнки у беременной женщины, с'ь благоголучншмъ исходомъ).

43. "Postrzeżenia dotyczące nauki o zarośnieniu pochwy macicznej." Gazeta Lekarska, pismo tygodniowe pośriẹcone wszystkim gałęziom umiejętności lekarskiej, farmacyi i wete. rynarji. Redakcje skladają: Brodowski, Chojnowski, Girsztowt i t. d. Tom 1. Warszawa, 1866. 8-vo. Nr. 7, str. 106-108; Nr. 8, str. $125-127$; Nr. 11 , str. $172-174$, Nr. 24, str. 377 -380 , i Nr. 26, str. 407-411. Z drzeworytami w tekscie.Oddzielne odbiçie. Warszawa 1867. 17 stronnic 8-vo. (Наблюденія касающил̈ся ученія объ атрезіи маточнаго влагалища).

44. „Przypadek habitualnego stawiania sie plodu do poro$\mathrm{du}$ w polożeniu poprzecznem, spowodowanego nieprawidłowa budowa macicy". Gazeta Lekarska i t. d. Tom 1. Warszawa, 1866. 8-ro. Nr, 15, str. 225-229.-Oddzielne odbicie. Warszawa, 1867. 5 stronnic. 8-vo. (Случай повторительно случагощагося поперечнаго положевія плода, вызваннаго неправильным'ь строеніем'ь матки).

45. „Postrzeżenia dotyczące nauki o mięsaku czyli sarkomacie warg sromowych". Gazeta Lekarska. Tom. 1. Warszawa, 1866. 8-vo. Nr. 19, str $289-292$; Nr. 20, str. 309--314, i Nr. 22, 
str. 347-350. Z drzeworytem w tekscie.-Oddzielne odbicie. Warszawa, 1866. 11 stronnic 8-vo. (Наблюденія к'ь ученію о сарюоматозной опухоли д'ътородных' губ́'ь).

46. „Przegląd ważniejszych przypadków chirurgicznych leczonych w roku 1862 do 1866 w szpitalu S-go Ducha w Warszawie" Gazeta Lukarska. Tom 2. Warszawa, 1867. 8-vo. Nr. 35, str. 556-560; Nr. 36, str. 570-573; Nr. 40, str. $634-640$, Nr. 41, str. $653-657$, i Nr. 43, str. $679-684$. Z 5 drzeworytami w tekscie.-Oddzielne odbicie. Warszawa, 1867. 23 stronnic 8-vo. (Перечень главп'ьйших' хирургических'ь случаевь леченныхт съ 1862 до 1866 года въ Больниц' Св Духа в'ь Варшав')

47. „Sprawozdanie z przypadków gyaijatrycznych w ciągu lat 1862-1866 w Szpitalu Świętego Ducha w Warszawie leczonych." Gazeta Lekarska. Warszawa. 8-vo. Tom 3, 1867: Nr. 4, str. 58: „Zapalenie jajników (ophoritis)."-Str. 59-61: „Przeistoczenie torbieliste jajników (degeneratio cystica ovariorum)."-Str. 61: „,Krwotok maciczny (metrorrhagia)." $-\mathrm{Nr} .4$, str. $61 ; \mathrm{Nr} .5$, str. $80-85 ; \mathrm{Nr} .10$, str. 157-159: ,Zapalenie macicy (metritis)."-Nr. 10, str. $159-161$; Nr. 13, str. 208210: "Rozrost szyi macicznej (hyperplasia colli uteri)." $-\mathrm{Nr} .13$, str. 210-21!: „Pिolipy maciczne (polypi uteri)." Nr. 14, str. 220 -223: „Brodawczak macicy (papilloma uteri)."-Nr. 14, str. 223 -224; Nr. 21, str. 332: "Gruczolak macicy (adenoma uteri)".Nr. 21, str. 332-333: ,Krwistek macico-pochwowy powstaly w nastepstwie braku otworu w blonie dziewiczej (haematocele uterovaginalis" [haemely trometra] ,ab atresia hymenis)." -- Nr.21, str. 333-336: „Przetoki moczowe (fistulae urinariae),--przetoki moczowodo-pochwowe (fistulae uretero-vaginales)."--Nr. 21, str. 336-337: "Włókniak macicy (fibroma uteri)."-Nr. 21, str. 337-338: ,Włókniako-mięśniak macicy (fibromyoma uteri)."Nr. 22, str. 351-354; Tom 4, 1868: Nr. 30, str. 478-483: „Wlókniako-mięsak macicy (fibrosarcoma uteri)."-Nr. 37, str. 593-597: "Mięsak macicy ( sarcoma uteri)."-Tom 5, 1868: Nr. 18, str. 277--280; Tom 6, 1869: Nr. 28, str. 435-437: „Rakowce czyli tak zwane kankroidy macicy (tumores carcinomatodes uteri)."-Nr. 28, str. 437-448: "Raki macicy (carinomata uteri)."-Nr. 33, str. 513-517; Nr. 41, str. 669-672; Nr. 44, 
str. 736-740: „Opadnienie i wypadnienie macicy (descensus et prolapsus uteri).”--Tom 8, 1870: Nr.31, str. 513-515: „Rozdarcie przegrody pochwo-wypustniczej i, śródkrocza (ruptura septi vaginorectalis et perinei)." $-\mathrm{Nr}$. 37, str. 609-613: „Przerost obydwóch warg sromowych więszych, tudziez wędzidelka tychże warg (elephantiasis)."-Tom 9, 1870: Nr. 12, str. 177180: „Przetoka pęcherzo-maciczna (fistula vesico-uterina)." $-\mathrm{Nr}$. 19, str. 295-297: ,Nimfomanija (nymphomania)."--Nr. 21, str. 321 - 324: "Nowotwory cewki moczowej (neoplasmata urethrae."-Tom 10, 1871: Nr. 50, str. 788-797: ,Dwa przypadki ropnia tkanki lącznej podskómej sromu i dwa-warg sromowych więliszych" [abscessus vulvae]. Tom 11, 1871: Nr. 1, str. 5-9: „Przerost elefantyatyczny lewej wargi sromowej więsszej" i t. d. [Elephantiasis labii pudendi majoris sinistri].Tom 12, 1872: Nr. 1, str. 4-10; Nr. 2, str. 20-24: "Choroby ssutki (morbi manmae)."- Nr. 2, str. 24-25: „Choro ciężarne.” -Oddzielne odbicie. Warszawa, 1873. 92 stronnic 8-vo. (Отчет"ь о гиніатрических'ь с.тучаях'ь леченных'ь в'ь продолженіи 1862 до 1866 года в'ь Больниц' Святаго Духа в'ь Варшав

48. ,Kilka slów o świetle palącego się magnezynu jako środku do badania torbieli plynem napelnionych i plynosteków w ogólności". Pamiętnik 'Towarzystwa Lekarskiego Warszawskiego. Tom 59. Warszawa, 1868. 8-vo. Str. 169 - 174.-Oddzielne odbicie. Warszawa (1868). 6 stronnic 8-vo. (Н'всколько слов'ь о св'ъть' горящаго магнезіума как'ь средства для изсл'вдованія кистьь наполненных'ь жидкостью и вообще водоскопленій).

49. „Przypadek dokonanej z pomyślnym skutkiem owariotomii" .Pamiętnik Towarzystwa Lekarskiego Warsámskiego. Rok 31. Tom 59. Warszawa, 1868. 8-vo. (Str. 180-191: „Posiedzenie Towarzystwa Lekarakiego Warszawskiego z dnia 18 lutego 1868). Str. 180-184. (С.гуай благошолучо произведенной оваріотоміи).

50. „Wycięcie jajnika (ovariotomia)". Gazeta Lekarska. Tom 4. Warszawa, 1868. 8-vo. Nr. 42, str. 665-669; Nr. 43; str 685-688; Nr. 45, str. 719-722; Nr. 46, str. 734-741, i Nr. 47, str. 751-756. Z dwoma di\%eworytami w tekscie.-Oddzielne odbicie. Warszawa, 1868. 23 stronnic 8-vo. 
51. „Bericht über eine mit Erfolg ausgeführte Ovariotomie". Monatsschrift für Geburtskunde und Fraucnkrankheiten, herausgegeben von Credé, Hecker u. s. w. Band 32. Berlin, 1868. 8-vo. S. 206-235. - Separat-Abdruck. Leiprig, (1868). 32 Seiten. S-vo. (Эта, равно как' и предшествующая статья относятся и'ь тому самому случаю оваріотоміи, который ошисан'в в'ь статьљ № 45).

52. „Sprawozdanie z ważniejszych operacyj gynjatrycznych w roku 1867 w Szpitalu Ś-go Ducha w Warszawie doknnanych". Pamietnik Towarzystwa Lekarskiego Warszawskiego. Rok 31. Tom 59. Warszawa, 1868. 8-vo. Str. 225-241.-Oddzielne odbicie. Warszawa (186S). 17 stronnic 8-vo. (Отчеть o ванн'ьйших'ь гиніатрических'ь операціяхь шроивведенных' въ продолженіи 1867 года в'ь Больниц' Св. Духа в'ь Варшавъ́).

53. "Wycięcie wielkiego guza macicy wraz z lewem jajnikieın (hysterovariotomia) z niepomyślnym skutkiem". Pamiętnik Towarzystwa Lekarskiego Warszawslii'go. Tom 61. Warszawa, 1869. 8-vo. Str. 241--252.-Oddzielne olbicie. (Warszawa, 1869). 12 stronnic 8-vo. (Выръзываніе большгои наточной опухоли вмъсть съ л'вьым яичником с'ь неблагонолучнымъ исходомъ).

54. „Hysterovariotomie mit ung(tustigem Erfolg”. Beitrage zur Geburtskunde und Gynaekologie, herausgegeben von F. W. von Scanzoni. Band 6. Wümburg, 1869. 8-vo. S. 125135.--Separat-Abdruck. (Würzburg 1869). 11 Seiten 8-vo-(Oтносится къ описанному в'ь стать' d: 52 случаю).

55. „Sprawozdanie z operacyj gynjatrycznych w roku 1868 w Szpitalu S. Ducha w Warszawie dokonanych". Pamiętnik Towarzystwa Lekarskiego Warszawskiego. Warszawa. 8-yo. Tom 62, 1869, str. $632-648$ i tom 63, 1870, str. 12-26.-Oddzielne odbicie. Warszawa, 1870. 30 stronnje 8-vo. (Отчет's o гиніатрических'ь операціях'ь произведенных'ъ в'ь 1868 году в'ь Больниц'в Св Духа в’ь Варшав')

56. „Przypadek jednostronnego krwisteku macico - pochwowego (haemelytrometra unilateralis), spowodowanego atrezja prawej polowy kanalu macico-pochwowego dwudzielnego." Pamiętnik Towarzystwa Lekarskiego Warszanskiego. Tom 63. Warszawa, 1870. 8-vo. Str. 167--179. Z dwoma drzenorytami 
w tekscie. (С.лучай односторонной маточно-влагалиццой кровяной опухоли вызванной атрезіею правой половины двойнаго маточновлагалищнаго канала).

57. „Najpraktyczniejszy sposób stosowania wstrzyskiwań leczniczych do pochwy". Pamiętnik Towarıystwa Lekarskiego Warszawskiego. Warszawa. 8-vo. Tom 63. 1870, str. 225-226 i tom 64,1870 , str. 284. Z drzewory tem w tekscie. (Самый практическій способъ пропзводства лечебных'ь впрыскиваній во влагалпце).

58. „Sprawozdanie $z$ ważniejszych przypadków operacyjnie leczonych w oddziale gyuijatryczno-chirurgicznym Szpitala Swietego Ducha -w Warszawie" (za rok 1869). Pamiętnik Towarzystwa Lekarskiego Warszawskiego. Tom 64. Warszawa, 1870. 8-vo. Str. 172-187, 236-250 i 292-312. Z drzeworytem w tekscie.-Oddzielne odbicie. War'szawa, 1870. 50 stronnic.

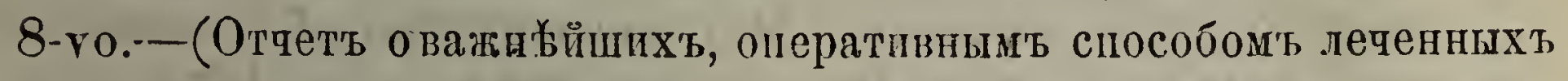
случалхъ въ Больниц'в Святаго Духа в'ь Варшав' [за 1869 годы]).

59. „Przyrodzone Fynicowanie pecherza moczowego oraz wypadniecie macicy (exstrophia congenita vesicae urinariae cum prolapsu uteri).". Pamiętnik Towarzystwa Lekarskiego Warszawskiego. Warszawa, 8-vo. Tom 64, 1870, zeszyt 6, str. 58 i 281 i Tom 65, 1871, str. 191. (Врожденный выворотъ мочеваго пузырья сопряженный съ выпаденіем'ь матки).

60. ,Przppadek porodu nieprawidlowego z powodu drgawek porodowych (eclampsia), przedwczesnego oddzielenia sie jaja i przodowania brzegu lożyska." Pamiętuik Towarzystwa Lekarskiego Warszawskiego. Tom 65. Warszawa, 1871. 8-vo. Str. 18-21. (Случай родов'ь пеправильныхъ по поводу эклямптических' судороі"ь, преждевремепнаго отдъвенія яйца и предтежанія края посльвда).

61. „Podwojny kanal macico-pochwowy." Pamiętnik Towarzystwa Lekarskiego Warszawskiego. Tom 65. Warszawa, 1871. 8-vo. Str. 21-23. (Случай двойнаго маточно-влагалищнаго кана. 7 ).

62. „Przypadek przetoki pęcherzo-macicznej." Pamiętnik Towarzystwa Lekarskiego Warszawskiego. Tom 65. Warкъзша, 1871. 8-vo. Str. 24-26 і 121-122. (Случай пузырно-маточнаго свища)." 
63. „Einspitige Haemometra bei zweigetheiltem Uterovaginalkanale in zwei lethal verlaufenen Fällen beobachtet." Archiv für Gynäkologie, redigirt von Credé und Spiegelberg. Band 2. Berlin, 1871. 8-vo. S. 246-272. Mit 2 Holzschnitten im Text.-Separat-Abdruck. (I،eipzig, 1871). 28 Seiten $8 \cdot$ ro.

64. „Ocalenie życia ciężarnej, z powodu wy górowanych wymiotów śmiercią głodowa zagrożonej, za pomocą sztuc\%nie wywolanego poronienia”. Pamiętnik Towarzystwa Lekarskiego Warszawskiego. Tom 66, zeszyt 1 . Warszawa, 1871. 8-vo. Str. 24-40.- Oddzielne odbicie. Warszawa, 1871. 16 stronnic 8-vo. (Спасеніе жизни беременной, которой чрезменрнал рвота угрожала смертью, посредствочь искусственно произведеннаго выкидыша).

65. „, Четыре случая сарбоматозной опухоли наружныхъ женских'ь половых' органов'ь." Медицинскій сборникъ, издаваемый Кавказким' Медицинским'ь Обцеством'ь. 스 11, май, 1871 год'ь. Тифлис'ь, 1871. 8-vo. Странницы 45-63. Съ рисунками въ тексть.

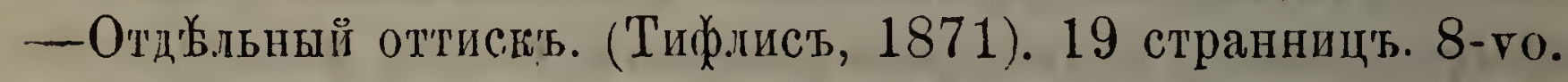

66. „Sprawozdanie \% przypadków gynjatrycznych w roku 1870 operacyjnym sposobem lecznnych w Szpitalu Świętego Ducha w Warszawie". Pamiętnik Towarzystwa Lekarskiego Warszawskiego. Tom 66. Warszawa, 1871. 8-vo. str. 92-98, $121-136,198-209$ i $237-248$.- Oddrielne odbicie. Warszawa, 1871. 52 stronnic. 8-vo. (Отчеть о гиніатрическихь случаях' в' 1870 году в'ь Больниц Святаго Духа в'ь Варнав' леченныхь оперативным's способом'ь).

67. "Kilka słow o potworach podwójnych czyli bliźniętach zroslych (monstra duplicia sive gemini coaliti)". Gazeta Lekarska. Redaktor i wydawca: Girsztowt. Tom 15. Warszawa, 1873. 8-vo. Nr. 2 (str. 17-26); Nr. 13 (str. $33-44$ ); Nr. 4 (str. 49 -58); Nr. 5 (str. 68-75); Nr. 6 (str. 81-85); Nr. 7 (str. 105 -107) i Nr. 8 (str. $116-118$ ).-Oddrielne odbicie. (Warszawa, 1873). 43 stronnic 8-то. (НАсколько слов' о двойных' уродах' или срощенных'ь двойнях'ь).

68. „Sprawozdanie z jæzy padków gynjatrycznych leczonych operacyjuie w Szpitalu Ś-go Dueha za lata 1871 i 1872 ". Pamiętnik Towarzystwa Lekarskiego Warszawakiego wydawany 
pod redakeya Feliksa Nawrockiego. Rok 1873. (Ogólnego zbio ru tom 69). Warszawa. 8-vo. Zeszvt 4. Strounice 357-387. (Oтчет'ь о гиніатрических'ь случалх' оперативным's способом'ь леченныхъ в’ь Њольницъ Святаго Духа за года 1871 и 1872).

69. „Figury niek tóry ch z ważniejszy ch narzędzi uży wanych przy leczeniu chorób wlaściwych plci żeńskiej przez Ludwika Nengebauera". Pamiętnik Towarzystwa Lekarskiego Warszawskiego. Rok 1873. Toni 69, zeszyt 4, str. 444-466. 40 drze-

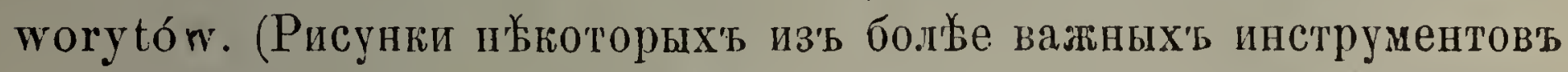
при леченіи женскихъ болъзней).—Статья 67 вм'ьст' со статью 68 в' отдъ.льномъ оттискъ: (Warszawa 1873). 54 str. 8-vo z 40 drzeworytami.

70. „Fizjologia i dyetetyka ciąży porodu i połogu. Z 302 drzeworytami w tekscie. Napisal Dr Ludwik Adolf Neugebauer". W dziele: Biblioteka umiejętności lekarskich, wydanie Redakcji Gazety Lekarskiej. Redaktor i wydawca: Girsztowt. Akuszerja. Tom pierwszy. Warszawa, 1874. 836 stronnic. 8. vо. (Фпвіологія и діэтетика беременности, родовъ и посльродоваго іееріода; сочиненіе составляющее первый томь Акушерства печатающагося въ сочиненіш: Biblioteka umiejętnosei lekarskich). 


\section{in}

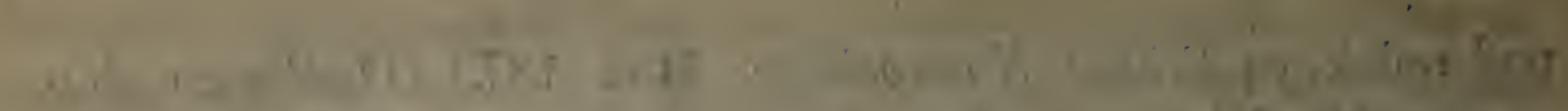

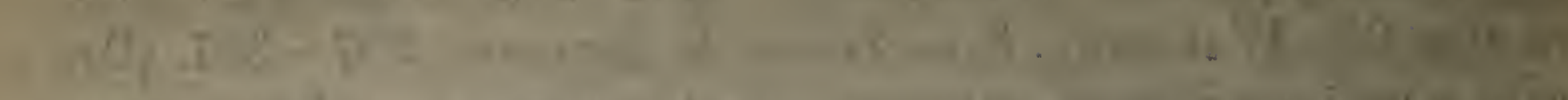

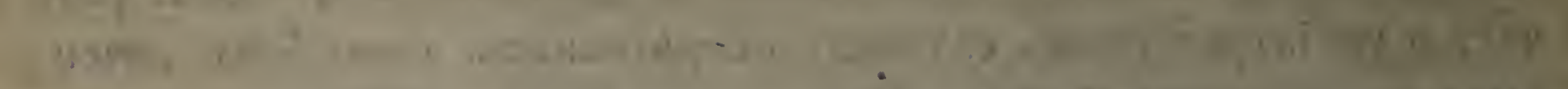

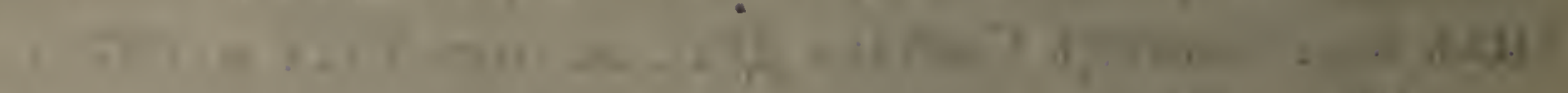

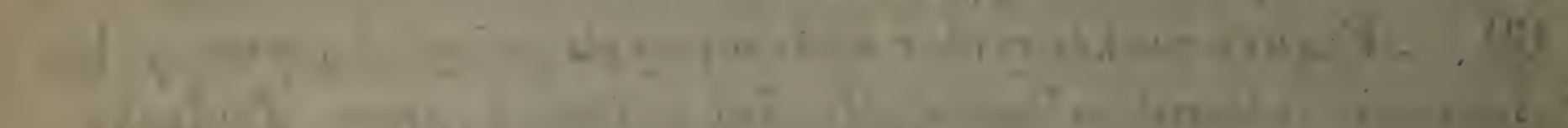

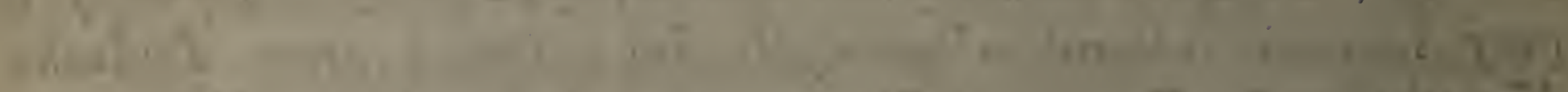

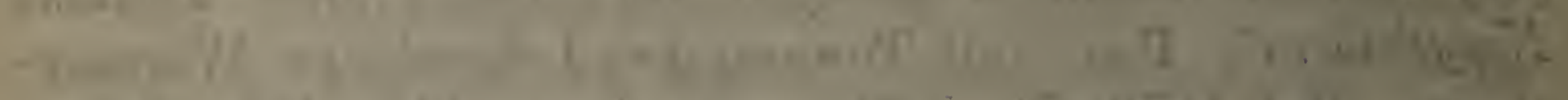

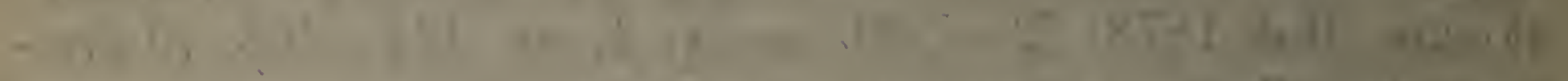

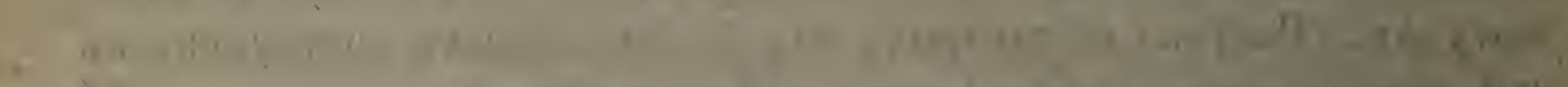

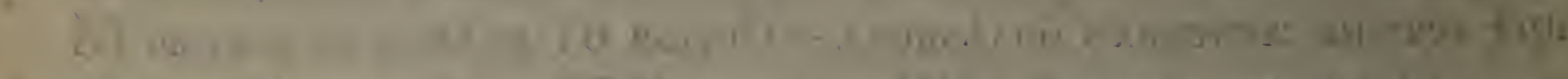

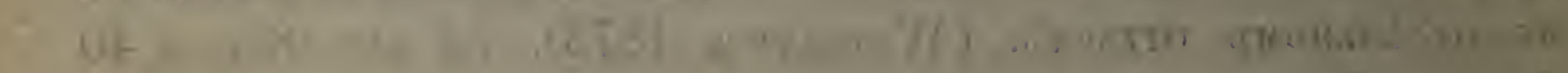
- wrines onit

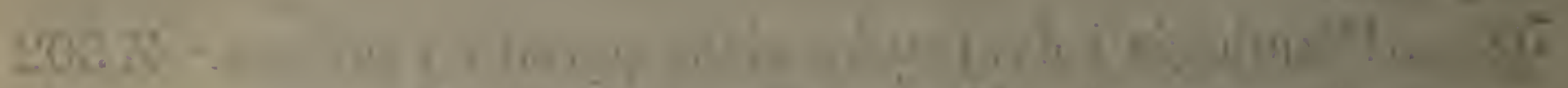
.

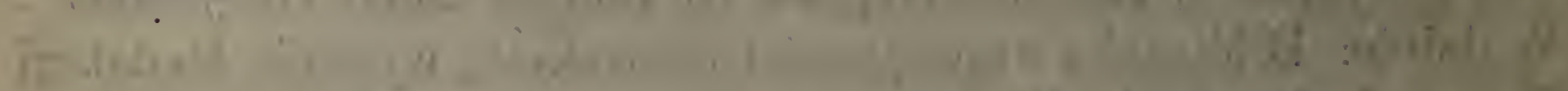

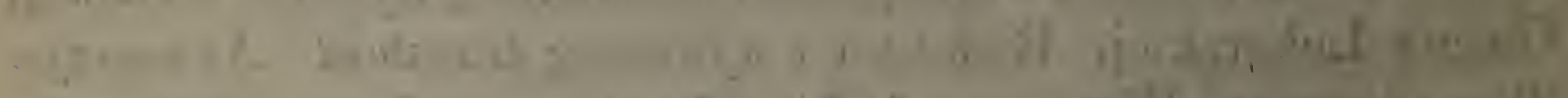

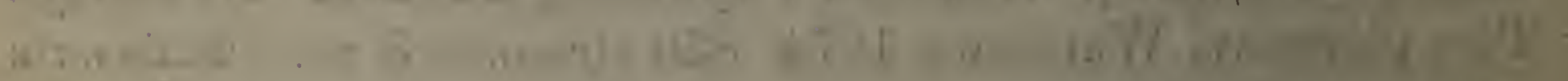

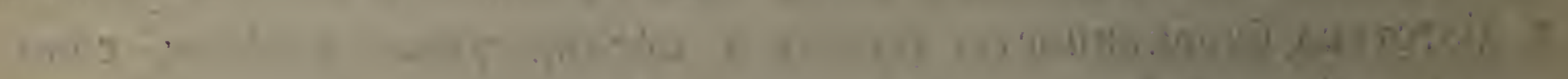

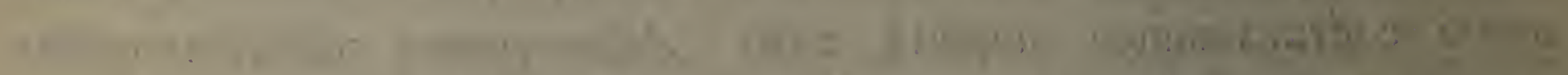

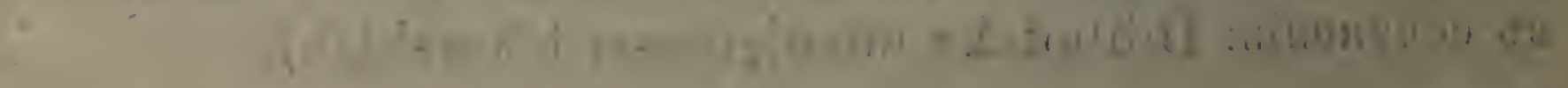

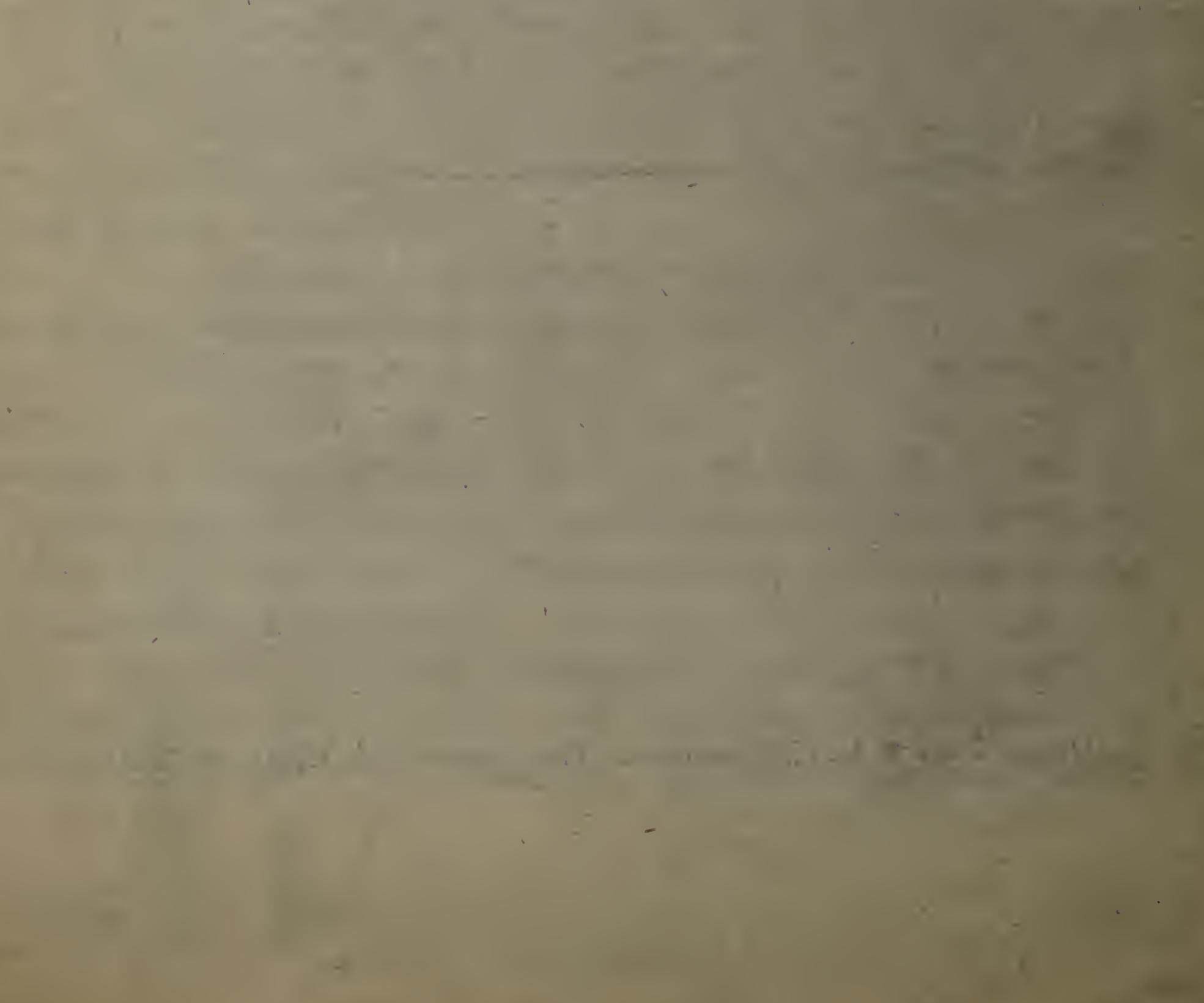

